\title{
Political and economic effects of post-election violence on national development
}

\author{
Sesan A. Peter and Imran AbdulRahman \\ Centre for Conflict Management and Peace Studies (CECOMPS), University of Jos, Jos, Nigeria. \\ Accepted 17 July, 2018
}

\begin{abstract}
One of the most recurring decimal in Africa is electoral violence mostly in the last three decades and it has turned to political nightmares in the midst of other related violence that have both political and economic implications on national development within the continent. Election is a cardinal stance within which political offices are held in democratic settings. Therefore, election is an attribute of democracy all over the world. However, the winner-takes-it-all that is attached to liberal democracy has made it peculiar that politicians tend to use all the powers within their means; be it money, power, intelligence and craftiness to ensure elections are won in their favour. The build-up, magnitude, and nature of electoral violence depend on a number of factors. These include the democratic integrity of the political parties; that of the Independent National Electoral Commission (INEC); the methods of siting polling units; and the distribution of voting materials (among others) This study examines the causes of post-election violence, its implications on both political and economic spheres and also proffers solution to the problems vis-a-vis national development. In line with this goal, documentary research methods were adopted. It was found that: (i) weak electoral laws, (ii) poverty, (iii) unemployment, (iv) hate speech (via social and media), and (v) lack of effective collaboration by security agencies leads to post-election violence. The study therefore recommends that: (i) a robust and strong inter-agency collaboration by the INEC to conduct hitch free election; and (ii) a weak law enforcement structure has been the reason for electoral violence.
\end{abstract}

Keywords: Democracy, election, electoral violence, post-election.

Corresponding author. E-mail: sesanpee@yahoo.com, aimran2007@gmail.com.

\section{INTRODUCTION}

The current global emphasis on democratisation has made election an inevitable process of leadership choice and succession, hence the need for routing elections globally. Election is the formal process of selecting a person for public office or of accepting or rejecting a political position. This is usually done in any democratic environment where people can be elected to various positions for a certain period of time. This is often accompanied with violence depending on the environment. Political violence, which constitutes a major challenge to stability in Nigeria and Africa in general, is a combination of pre and post-election violence that can lead to chaos and instability in the polity. This particular problem has become a recurring decimal in Africa and in Nigeria in particular. This could come in the form of election campaign and other forms of violence attributed to electioneering and its effects on the national development cannot be ignored.

According to Igbuzor (2010), electoral violence is: 'any act of violence perpetuated in the course of political activities, including pre, during and post-election periods, and may include any of the following acts: thuggery, use of force to disrupt political meetings or voting at polling stations, or the use of dangerous weapons to intimidate voters and other electoral process or to cause bodily harm or injury to any person connected with electoral processes.' These kinds of violence are not new in Nigeria as such having been recorded from the 1980s in the southwest to the recent post-election violence of 2011.

There is an emerging identity that election is breeding in Nigeria and it appears it is currently dividing the country along ethnic and religious dimension. Protest against a candidate can easily be traced along ethnic and 
religious divide. For instance, the post-election violence of the 2011 presidential election occurred mostly in Hausa/Fulani communities of northern Nigeria because the people interpreted the loss of Mohammadu Buhari in a religious and ethnic way. In the words of Paden (2012), 'the presidential election on April 2011 split the country along religious and regional lines and produced a violent post-election rampage'. This is not different from the opinion of Jega (2011) shortly after the election.

Again, some of the underlining issues that culminate into post-election violence in Nigeria are also rooted in pre-election arrangements on the part of INEC and internal party democracy, the integrity of the election, inter-agency problem and delay in the distribution of sensitive materials to the various polling booths on the day of election. Sometimes, the choice of who would contest during the party's primaries also determines if there will be post-election violence or not. In another instance, the candidate that was replaced with another candidate can form a coalition for violence during and after the election

There is also the issue of money bags during elections where the staff of INEC (including the adhoc staff) and security agencies are monetarily induced to compromise electoral process in favour of the government of the day or party can lead to post-election violence especially where it is glaring to the opposition and the electorates decide to react. Post-election violence does not come from the blues; there are reasons that build up to the violence ranging from pre-election and during election. In carrying out this study, qualitative research method was adopted. The study made use of books, articles, journals, reports and internet sources.

\section{Conceptualization}

This section discusses the meaning of various terms used by different scholars on the subject matter. The key terms conceptualized are election, violence and electoral violence.

\section{Election}

Election has been defined as the manner of choice agreed upon by people out of many to occupy one or a number of positions of authority (Nnoli, 1978). Elections have always been the legitimate way of transferring power from one regime to another through the ballot box. Through election, popular conduct and participation in public affairs is created in the society (Ugoh, 2004).

\section{Violence}

The word violence has been viewed from different angles by different scholars from distinctive standpoints. Thus, for the purpose of this discourse, we are looking at violence in terms of both violation of human rights and social injustice. According to Gilula and Daniels, violence is 'destructive aggression'. This conceptualization of violence implies the use of physical force to injure persons or destroy properties; and this is the core of most definitions of violence.

\section{Electoral violence}

According to Fischer, electoral violence (conflict) as any random or organized act that seeks to determine, delay, or otherwise influence an electoral process through threat, verbal intimidation, hate speech, disinformation, physical assault, forced "protection", blackmail, destruction of property, or assassination (Fischer, 2002). This definition is all encompassing and it has captured the essence and focus of the present study; therefore, this definition is adopted in the course of this study. Today, all the variables mentioned in Fisher's definition are prevailing in the polity of Nigeria and this is leading to violence both on the social media and in reality.

Electoral violent mostly occurs in the conduct of an electoral contest before, during, and after elections. Most often they are directed at altering, influencing, or changing, by force, the voting pattern or manipulating the electoral results in favour of a particular candidate or or political party (Ugoh, 2004).

\section{Theoretical framework}

The theoretical framework adopted for this research is the relative deprivation theory; the theory of relative deprivation is one of the most popular behavioural explanatory frameworks utilized in the study of violence. This theory was propounded by the following scholars: John Dullard-1939, Leonard Berkowitz-1962, Ted Gurr1970, James Davies-1972 etc. The fulcrum of the theory is that aggression and violence is always a result of frustration and anger due to discontent of the individual or group concerning what he/they perceive as his/their due, and what he/they actually get(s). Every violence is a result of unmet expectations. People tend to be aggressive when they are frustrated and denied their rights. In other words, it is the degree to which the group/individual feels deprived and its related anger and frustrations as mentioned above that often instigate violence. People normally result to irrational behaviour and violence if they feel an intense of relative deprivation. Emphasis is on intensity and scope. In other words, if social want formation exceeds social want satisfaction, then the consequence consequences is social frustration which may lead to violence.

However, by way of definition, Gurr (1970) conceptualized deprivation as a perceived discrepancy between, value expectation and their value capability. 
Value expectations are the goods and condition of life which people believe they are rightfully entitled to. Value capabilities are the goods and conditions of life they are capable of attaining and maintaining, given the social means available to them.

This relative deprivation framework can be used to explain the 2011 post presidential election violence which is said to have broken out in Northern Nigeria as a result of the masses' frustration against their political elites and traditional rulers that were believed to have worked against their collective value expectation. The discrepancy between value expectation (of different candidate of any political party to win election) and value satisfaction (the outcome of the election) led to frustration and aggression which culminated in the post-election violence. The mantra of change of political power by majority witnessed a dramatic challenge of the status quo of the masses toeing whatever the traditional say or do. For the first time, the youth did not only seek to vote in opposition of the direction of traditional rulers and the political elites, they also sought for accountability from leaders whom they believed to have been 'induced' monetarily for the role they played in re-electing the incumbent government. It is however important to acknowledge that the preponderance of poverty and illiteracy in the society, heightened by hate speech dominated campaign, became accelerating factors for the scale and spread of violence in some of the northern states.

\section{CAUSATIVE FACTORS OF POST ELECTION VIOLENCE}

This section looks at the institutionally induced factors and socio-economic and political factors which have often led to post-election violence. The institutionally induced factors are anchored on action or inaction of those institutions that have key role to play prior, during and post-election period. These include such institutions as: the Political parties; Independent National Electoral Commission (INEC); and the Police along with other security agencies that have roles to play depending on the context. The Immigration service may be key player where foreigners that have no voting right are being engaged in political activities illegally. It also includes those institutions that are core and tangentially relevant to the conduct and credibility of the electoral process and results. The National and International observers as a recognised unit in the reviewed Electoral Act to prosecute certain observed irregularities in elections in Nigeria; the media and the applauded inclusion of the use of University community (academics) and National Youth Service Corps (NYSC) who are mostly recruited as ad hoc staff during elections as presiding officers and electoral officers are all important in the overarching strategic plan towards a free and fair election that could mitigate post-election violence. The social, economic and political factors as instrument to electoral violence are also discussed along with the institutional factors in this section.

\section{Institutional factors that triggers off post-election violence}

\section{Lack of party internal democracy}

A build up to election where candidates that will stand for parties will be selected among the party stalwart has led to post-election in Nigeria. A build up to election in which candidates are not selected through due process at the party primaries (but are rather imposed on the people by party elite) will likely end in violence. Every candidate that wants to contest for election ought to go through the due processes of networking within the party and then contest within the party; this will give a fair opportunity for all the candidates. According to Peter and Dalyop (2014), internal practice of democratic principles of a political party determines its public exhibition of democratic principles. Political parties must allow internal democracy to prevail if standard must be set and maintained. However, a situation where such candidate is imposed on the party, depending on the capacity and or influential supporters on the other candidate's side, the party decision may be a call for electoral violence. According to Sisk (2008) this may instigate pre-election violence which can take the form of inflammatory rhetoric, attacks on politicians, and party supporters. Zagga and Sani corroborate Ofili (2011) in attributing the commencement of post-election violence to the pre-election stage inflammatory statement that supporters may construed as a call for violence.

\section{INEC pre-election arrangement}

The Independent Electoral Commission has the primary mandate to conduct and announce election. Delay in the release of election time table can be seen by certain group of people in the society as a grand plan to sabotage their effort at winning election at the poll. Any alteration in the election time table without due consultation and publicity to all the concerned stakeholders which may give advantage to any particular group may be a reason for protest by those disadvantaged by that decision. Such protest could lead to violence (by supporters of the disadvantaged group) after the election result has been announced. For instance, 2015 Presidential election was postponed at very close period to the election and was seen by the opponent that government was using INEC to change dates in order to buy time; however, the opponent eventually won the election which doused the tension. The fact that there was no violence in 2015 post-election was simply that the government of the day did not use 
force to maneuver the result and the opponent won which would have been a reason to have accused the government of the day of rigging the election and that would have had a similar violence to 2011 election where the supporters of the opposition went after traditional rulers especially in the north perceived to be supporting the ruling party (PDP) at that time. It was widely believed that the additional period with which the election was extended allowed the government of the day to send in monetary incentives (bride) to number of political stalwarts and traditional rulers with the intention of influencing the pattern of voting and the outcome of the election. This seems to be established by the APC government with the so-called 'Dasuki-Gate' scandal which resulted in the prosecution of former President Jonathan's National Security Adviser, Colonel Sambo (retired) and others for money allegedly looted and shared to politicians and their cronies before and during the elections.

Again, the arrangement of INEC on the movement of sensitive and non-sensitive materials to the local environments where they will be used for accreditation and subsequent elections should be well-managed and tidied up before the commencement of voters' accreditation. In this case, all agencies that need to work in tandem with INEC to see to the success of elections must collaborate with INEC if electoral issues must be avoided. The security of the sensitive materials to the end users should be carried out by the security agencies in conjunction with INEC. This is to ensure that all agencies work in line with INEC to ensure that election materials are well secured while being transited to the places where they are needed. During the elections, the framework regulating the conduct of the election must be publicized to the electorates and made enforceable. For instance, the issue of 'no movement' during election and ban on campaign a day to the election must be enforced. These are the issues that can lead to post-election violence in Nigeria.

\section{Money politics and money bag}

The unregulated use of money in politics has become a popular phenomenon. This is owing to non-adherence to existing regulations on party finances and the absence of strict legislation to regulate limits of individual party finance, made it possible for politicians and political parties to engage in illegal party financing and corruption since the Nigeria first Republic (Adetula, 2008). It is wellknown fact that nothing serious can be carried out in political terrain without money but the manner in which money is used during electioneering campaign cum election period is called for a caution. When money is used to influence the outcome of an election, it can affect the genuineness and integrity of the election. In this case, INEC cannot do this work alone; it has to be done along with other agencies such as EFCC and DSS to monitor the spending of candidate during the campaign exercise.

\section{Election integrity and rigging}

This is one of the immediate causes of post-election violence in Africa. Election rigging refers to any interference in the due process of election in order to give undue advantage either to a candidate or a political party. Even a seemingly harmless act as late delivery of electoral materials can lead to a major disadvantage to one party; thereby triggering post-election violence Lack of electoral integrity has led to several post elections violence in several countries in Africa. Electoral integrity is even more problematic in countries such as Nigeria where ethnicity is salient in politics. In such societies, the victory or defeat of a particular candidate or party is perceived as victory/defeat of an entire community or religious group. As such, any form of irregularities that would prevent a candidate or his/her community from clinching electoral victory is often opposed, sometimes violently, by the entire community (Orji, 2010).

Post-election violence has plagued other African countries, often along ethnic and/or regional lines. Examples such as Democratic Republic of Congo, has witnessed violence after its election of November 28, 2011 the second election held in the country since the end of a civil war that left millions of people dead (Paden, 2011). The Ethiopian scenario and the Kenyan case are good examples of rigging. In Kenya, the incumbent swore himself into the office of President even in defiance of a court ruling which affirmed his defeat at the polls. All these show that rigging is a serious problem in Africa.

There are key lessons to be learned from the postelection violence in Ethiopia, Kenya and Nigeria. The first is that the experiences of the three countries show that electoral violence is deeply-rooted in the countries' historical, political, and socio-economic configurations, and were only triggered by election outcomes, including allegations of electoral fraud. Electoral violence in Ethiopia was shaped by the domination of the country's politics and governance by Ethiopian People's Revolutionary Democratic Front (EPRDF), under the control of Tigray and Amhara elite. In Kenya, the 2007/08 electoral violence was underpinned by the exclusion of the Luo in governance, while the 2011 post-election violence in Nigeria was underlined by the supplanting of the Muslim/Hausa-Fulani community in national politics. This shows the continued saliency of ethnicity despite efforts towards moderating the influence of communal identities in African politics. Identity politics remains a major challenge to peace, security and stability in Africa (Paden, 2012).

On the part of Nigeria, the elections of 1964 and 1965 split the country along regional lines and plunged it into one of the worst civil wars in African history, with approximately two million dead (most from famine and resultant diseases). Much of the postwar effort in Nigeria 
was focused on devising mechanisms so that "never again" would such trauma repeat itself in Nigeria. However, it appears the younger generation of Nigerian leaders have neglected the nation unity consciousness and toed the path of selfishness at the detriment of the entire nation through ethnic and religious lines. This pattern had continued till 2011 post-election upheaval in Nigeria.

In the aftermath of the 2011 election Bishop Kukah observed, "the results of the April 2011 general elections indicated that the country was drifting towards regional politics to the detriment of national unity" (Paden, 2012). This statement is further corroborated by Jega (2011). This has become the reality in Nigeria and some African countries and if this continues there may be no genuine elections in Nigeria. No wonder Huntington (1996) predicted that 'Nigeria is a cleft country and destined to split along religious lines'. This prediction is already manifesting itself in the nature of elections taking place in Nigeria where election is predicated on ethnic or religious cleavages that discourages national unity and development to be the prime focus.

\section{Socio-economic factors}

At the roots of electoral violence in Nigeria are several issues some of which do not have any direct relationship with the country's electoral process. These issues define the ways electoral violence can play out.

This factor is divided into two: poverty on the part of the electorate (mostly youth) and the investment of the politicians in the elections with the hope of recouping their money back after election. Politicians that have invested will want to ensure they win by all means since power will be concentrated in the hands of the office holders. This is closely linked with the concept of the winner takes it all' as described by Joseph (2010), where he describes it as 'prebendal politics'. The concentration of resources in the state makes the possession of state powers a means to the end of controlling state resources. The system of prebendal politics spurs individuals, groups, communities and constituencies to seek to capture state power in order to control state resources. Those who are already in control of state power often hold strongly on to it by suppressing their opponents. Under this circumstance, the democratic tradition of alternation of power among individuals and political parties is difficult to achieve. This same prebendal politics has led to ethnic politics in Africa. Every election conducted in Nigeria is divided along ethnic lines.

\section{Poverty and unemployment}

This is another economic factor that has tendency to cause post-election violence in Africa. For instance, the high level of unemployment among the youth has made elections to become "do or die" affairs. Politicians are capitalizing on the issue of unemployment to recruits young men into their various camps to support their bids to win in an election. These young people might be collecting little amount of money as salaries from their "god-father" and sometimes with the promise of giving employment after winning elections. Of a truth, this has made youths to indulge in thuggery with the hope of being compensated with job opportunity after election. Again, there is a nexus between unemployment and poverty among the youth. It is when the youths are empowered or gainfully employed that poverty can be reduced for them and their families, hence there is reduction in violence related activities.

\section{Electoral knowledge and illiteracy}

The majority of the people that vote during elections are uneducated people mostly from the villages. These people have no understanding of certain crimes therefore they can be used to foment violence especially before, during and post-election. High level of illiteracy and poverty combined has threatened national development. This is because the number of poor people is higher in Africa and this group of people can be used to cause havoc in the society. Aniekwe and Kushie (2011) succinctly put: Members of these gangs are mostly illiterate, unemployed and poor young men, who are mobilized to attack their sponsors' rivals, intimidate members of the public, rig elections, and protect their patrons from similar attacks. Again, Jega (2011) attributed the causes of the election violence to related systemic issues such as poverty and unemployment, illiteracy and lack of proper education, poor political enlightenment and voter education, rather than the actual conduct of election, and even less of ethno-religious factors as opined by some analysts.

\section{Lack of trust among ethnic groups communities}

Since the era of colonial masters, it has been duly registered in Nigeria among ethnic groups and communities that trust is no longer a potent tool to live with. The colonial masters destroyed the trust among the people on the ground of 'divide and rule' tactics, and this has continued unabated among the people even within the same community. Scholars such as, Plotnicov (1971), Nnoli (1978), and Albert (1995) presented lucid accounts of these inter-group clashes. Years of violent confrontations by various communal groups in Nigeria have eroded trust and social capital existing in the communities, making the communities vulnerable to political manipulation. Communal tensions not related to elections can degenerate into bloodshed during elections. Many ethnic groups have resulted into open confrontations as a result of distrust that exist among the people. 


\section{Political intolerance}

Inability to tolerate one another can be a cause of postelection violence. This is seen in a situation whereby hardly do election losers accept the verdict of the ballot box. For instance, in all three times from 2003 to 2011, Muhammadu Buhari went to the electoral tribunal to contest the verdict of every election he lost. He never accepted any of the lost elections as free and fair. No wonder Jega (2011) blamed the post-election violence on what he termed as "Crisis of Expectation". When the choice of the people or kinsman does not win an election it then means the outcome of the election is not credible. This has led to post-election violence in Nigeria. For example, after the presidential announcement of 2011 election while the appeals panel began its work, Buhari withheld his endorsement of the election. His key supporters insisted on taking the results to the tribunal and he wanted to respect the process. However, according to an account in Daily Trust (2011) Buhari vowed not to congratulate the then President Jonathan until his demands were met... This eventually led to violence in the northern part of the country mostly in 2011. Electoral intolerance has multiplier effects on the national development of the nation.

\section{Social media and hate speech}

There is an emerging platform called social media in Nigeria which has come with its own weakness. Social media is an online platform where people can make comments on topical issue within the society. Social media platform can sometimes be riddled with hate speeches. Peter and Adeniyi (2017) sees hate speech as any utterance that has tendency to cause harm on the image, psyche and belief system of the people within the society. This is becoming a serious problem in Nigeria. People can make comments or allegations which are not supported with facts or concrete evidence; and these can be spread within seconds to cause violent conflict. According to Gagliardone et al. (2015), online hate speech is not essentially different from similar expressions found offline; however, there are some specific characteristics as well as challenges unique to online content and its regulation. They summarized these characteristics as permanence, itinerancy, anonymity or pseudonym and trans-nationality. Therefore, people must have Media Literacy Intelligence (MIL) to discern between truth and fiction.

\section{Proliferations of arms}

Weak legislation against the Proliferation of arms and Light Weapons (SALW) has contributed to post-election violence in Nigeria. The exit and entry of arms from the porous borders have also contributed to armed conflict as a result of electoral violence. Sometimes, during electioneering campaign, thugs were seen carrying arms to unleash terror on the innocent electorates and after the elections the arms remain in circulation. This is why even after elections the arms are used for one act of criminality or the other. The nature of armed conflict has changed over time as a result of proliferation of small arms and light weapons into the country. In the past, bows and arrows, machetes and knives were the main instruments used in armed conflict which had less severe impact as compared to the currently used arms (such as guns of all sorts, Improvised Explosive Devices (IEDs) and other arms that can cause collateral damages within few minutes).

\section{Weak legal penalties}

The legal framework guiding electoral process and violation seem to lack enforcement. Nigeria has not prosecuted much violator irrespective of the damage they have caused in the past. The criminal or penal code of a nation spells out crimes and the penalties or punishment for violators of the code. Penalties or punishment are intended to achieve correction, retribution and deterrence. In Nigeria, there are no specific legislations against certain electoral offences, only for associated acts like arson, assault and murder. The laws for example, have no provision for the snatching of electoral ballot boxes from polling booths (a common crime during elections). Moreover, the penalties for acts associated with electoral violence like assault and arson, are generally weak; a few years imprisonment at most. This has contributed to the culture of impunity and underscores the need to review the extant laws.

\section{POLITICAL AND ECONOMIC EFFECTS OF ELECTORAL VIOLENCE ON NATIONAL DEVELOPMENT}

Post-election violence poses negative impact on national development irrespective of the environment where the violence is committed. However, the effects of postelection violence on national development are as follows:

\section{Political instability}

Nigeria believes in winner-takes-all and lack of the spirit of sportsmanship. When you lose be humble enough to prepare for the next election. The emergence of violence makes the opponent to capitalize on the unhealthy environment to challenge the election. Election challenge also slows down the pace of development and this makes political office holders to engage in primitive accumulation 
of wealth and does not allow them to concentrate on governance and development suffers.

Electoral violence is both causative and symptomatic of political instability in Nigeria. It is symptomatic as it reflects an inchoate political system. It is also causative because it feeds the political crises that manifest regularly. Electoral violence, if not properly addressed, could ultimately lead to escalated violence. Escalated violence can lead to death in the country. For instance, 2011 post-election violence according to Kaduna State Government (2011), 'the 2011 post-election violence seems to be most intense in Kaduna where the highest number of deaths and destruction were recorded. Figures released by the Nigeria Police indicate that 401 people were killed during the post-election violence in Kaduna State'. Kaduna state had experienced series of violence conflict including the Zango Kataf crisis in 1993, sectarian clashes sparked by Christian protests against the introduction of Sharia law in 2000 , as well as sectarian violence triggered by Muslim protests linked to the hosting Miss World beauty pageant in Nigeria. Ever since the Zango Kataf crisis in 1993, relationship between Christians and Muslims in Kaduna State has been tensed up till the experience in December 2016 where lives and property were lost in communities like Godogodo, Goska, Dangoma, Chawei among other communities. Years of repeated sectarian bloodshed have produced deepseated animosity among the two religious communities. Like other animosity conflicts, memories of past conflict have acquired a relative autonomy, and become significant in renewing and intensifying the violence that occurred in many parts of Kaduna State (Ibeanu, 2003).

\section{Political apathy}

As a result of previous effort of voters not counting during election, most voters are not sufficiently motivated to exercise their franchise because people believe that their vote may not count. The apathy is also worsened by economic situation whereby thugs are recruited to disrupt and harm the electorate because they have been bribed or induced with drugs. Therefore, poverty is a reflective of the apathy.

\section{Economic effects on national development}

Investment in violence through arming of unemployed youth with Small and Light Weapons and drugs as a driving force to destroy the fabric of any nation (youth) for the purpose of electoral violence. A large number of this youth who are unemployed, underemployed and those that are unemployable are used to free money coming from political thuggery and violence during the course of post-election violence. On one side, the deadly acts of these thugs terrorizing lives and property during the elections are the youth themselves, some of them became drug addict since there is no political contract to pursue thereby turning to armed robbers, kidnappers and assassin in the long run as a result of access to weapons during electioneering. Today, Nigeria is paying for kidnapping and other criminality in the society as a result of political gangsterism and other vices.

Post-election violence also has negative effects on economic activity of the society, when a large-scale violence breaks out minimum level production is lost as people scamp for safety. Where there is no enough security to checkmate the vandalisation of property, the hoodlums take over the environment to brutalise innocent people which endanger the generality of the society.

The period of violence is a period where development is often distracted. The available infrastructures such as schools, hospital, pipe borne water facilities and other government institutions are being destroyed. The resources government is meant to use to development the system will then be diverted to cater for security, rehabilitation of destroyed facilities and this will hamper development.

\section{Human displacement}

Violence generally leads to displacement of people. People tend to run away from their ancestral abode in search of safety and this has become a major problem confronting African countries. People can be displaced internally while other can become refugees especially for those who run across borders to another country for the purpose of security. Alubo (2011) in Aver (2013) asserts that the refugee problems that accompany these disturbances also have implications for attainment of target in, and access to social development such as education, reduction in maternal mortality and childhood deaths as well as other aspects of productive health'. Again, this has led to increase in humanitarian emergencies. According to the Human Rights Watch (2011:1), the 2011 post-election violence forced more than 65,000 people to flee their homes and were camped at various locations in Kaduna, Bauchi, Gombe, and Kano, Niger, Sokoto, Anambra and Plateau states among others.

\section{Effect on women and children}

Women and children are usually the worst hit during violent conflicts. Women can be victim of rape, and sometimes when their husbands are killed, the women then begin to suffer in order to cater for the welfare of the family. According to Aver et al. (2013), the mass rape of the female population in the areas engulfs by violence fuels the spread of HIV/AIDS which is already a high prevalence and regarded as a social problem in Nigeria. 
Furthermore, the continued eruptions of political violence have implications for national peace and security, and thereby threaten the dissolution of the country Nigeria. This leads to psychological trauma on the part of women and children in the society. A large number of people suffered bodily harm inflicted with dangerous weapons such as machetes, cutlasses, and arrows. In one incident, a police officer was bathed in hot oil (Asemota, 2011:8).

\section{CONCLUSION}

Electoral violence in Nigeria is triggered by a number of factors; include poverty/unemployment, ineffectiveness of security forces, proliferation of small arms, and the emergence of social media platform and hate speech among others. One of the basic issues to be handled with all seriousness is the issue of unemployment among the teeming youth. The youth have gone to university for education and when they are not gainfully employed the rippling effect is much on the society. The experience in school must be put to use in one way or the other. Skill acquisition and vocational training for the youth is important to reduce the number of youth being used during electioneering in the society. When this is done, electoral violence will be minimized.

Government must ensure that the security agencies especially the police are well-trained and re-trained in order to be abreast with the current method of handling violent conflict in the society without them recording more causality among them security forces and the civilian. The security agents must be motivated by a way of ensuring that their pay is good enough for them to risk their lives when it comes to violence containment. Again, Violators of electoral laws should be brought to book without fear or favour. This will serve as deterrent to others who plan to foment trouble including the politicians themselves. When the rule of rule is allowed to take its course, the level of violence during electioneering will reduce.

The issue of social media that is left uncensored must not be allowed to persist; the legal framework regulating cybercrime should be strengthened especially Cybercrime Act 2015. The law should be enforced to reduce the issue of hate speech going on the platform. Again, mass media should be properly guided to reduce the level of negative comments going on either on the ground of ethnicity, religious or political ground. By so doing, the tendency of violent conflict will be minimized. Finally, to repair the damage done by past post-election violence, Nigeria needs wise and principled leaders to manage the symbols of division at work in Nigeria both at national and local levels. The political calculations of leaders at all levels must give recourse to issues that will unite the country and not the issues such as ethnicity, religious and regional animosity that will cause more harm to the national development.

\section{RECOMMENDATIONS}

The study recommends the following:

There should be an inter-agency collaboration to prosecute election in Nigeria. For instance, INEC should work with other agencies such as University, National Youth Service Corps (NYSC), the Police, Air force, Navy, Civil Defence and the Military during election for adequate security and to prompt delivery of electoral materials.

INEC should be properly funded to make proper arrangement for the conduct of the election including materials readily available weeks to the election. INEC should also liaise with relevant agencies that would be needed during election and spell out their job descriptions prior to the period of election.

INEC should step up her collaboration with the National Orientation Agency (NOA) and Civil Society Organisations for civic education on pattern of voting and the danger of post-election violence.

Rule of law must be upheld concerning electoral matters. Pre-election grievances such as lack of internal party democracy, party financing and campaign process should be sorted out within a short period.

The institution responsible for the conduct of election process should accommodate those in the Diaspora without manipulation. The post-election violence that was induced as a result of administrative issue would have been tackled.

\section{REFERENCES}

Adetula, V. A. O. (2008). Money and Politics in Nigeria: An Overview (ed). Abuja: IFES.

Albert, I. O. (1995) Inter-Ethnics Relations in a Nigerian City: A Historical Perspective of the Hausa-Igbo Conflicts in Kano 19531991. Ibadan: IFRA.

Aniekwe, C., and Kushie, J. (2011). Electoral Violence Situational Analysis: Identifying Hot Spots in the 2011 General Elections in Nigeria. Abuja: NAPEN.

Asemota, A. (2011). 7 Killed, 65 Churches Burnt in Katsina. Sunday Sun [Lagos], 24 April.

Aver, T. H., Nnorom, K. C., and Targba, A. (2013). Political Violence and its Effects on Social Development in Nigeria. International Journal of Humanities and Social Science, 3(17): 261-266.

Buhari, M. (2011). Why I didn't Congratulate Jonathan. Daily Trust, May 2, 2011.

Fischer, J. (2002). Electoral Conflict and Violence. IFES, Washington, D.C.

Gagliardone, I., Danit, G., Thiago, A., and Gabriela, M. (2015). Countering Online Hate Speech. France: UNESCO publishers.

Gurr, T. R. (1970). Why Men Rebel. Princeton University Press.

Huntington, S. P. (1996). The Clash of Civilization and the Remaking of World Order. New York: Simon \& Schuster.

Igbuzor, O. (2010). Electoral Violence in Nigeria. Asaba: Action Aid Nigeria.

Jega, A. (2011). Blames post-election violence on "Crisis of Expectation". Daily Trust online, Retrieved July 6, 2011.

Joseph, R. (2010). Elections and Democracy: Restoring Nigerian Leadership. Public lecture to mark Nigeria's 50th anniversary, Abuja and Lagos, October 2010.

Nnoli, O. (1978). Ethnic Politics in Nigeria. Enugu: Fourth Dimension Publishers. 
Orji, N. (2010). Responses to electoral outcomes: The aftermath of 2007 elections in Nigeria and Kenya. African and Asian Studies, 9(4): 436-461.

Paden, J. N. (2012). Postelection Conflict Management in Nigeria: the Challenge of National Unity. USA: George Mason University.

Peter, S. A., and Adeniyi, M. A. (2017). Linking hate speech as the Constraint to Peace-Building process in Southern Kaduna: Implication on Youth and Children. Paper Presented at the $22^{\text {nd }}$ NASA's Annual National Conference held at University of Ibadan $6^{\text {th }}$ $9^{\text {th }}$ November, 2017.

Peter, S. A., and Dalyop, D.D. (2014). Intra party democratic practices in Nigeria: Implications for political and economic development. Taraba Journal of Political Science and International Relations, 1(1): $1-21$

Plotnicov, L. (1971). An Early Nigerian Civil Disturbance: The 1945 Hausa-Ibo Riot in Jos. Journal of Modern African Studies, 9(2): 297305.

Sisk, T. (2008). Elections in Fragile States: Between Voice and Violence. Paper Prepared for the International Studies Association Annual Meeting, San Francisco, California, March 2428.

Ugoh, S. C. (2004). Electoral malpractice and violence in the 2003 general elections in Nigeria. UNILAG Journal of Politics. Vol. 1, No 1.
Citation: Peter, S. A., and AbdulRahman, I. (2018). Political and economic effects of post-election violence on national development. Net Journal of Social Sciences, 6(2): 18-26. 